\title{
The experience of HIV reactive patients in rural Malawi - Part I
}

\author{
Y Sliep, D.Cur(Student), Department of Nursing, RAU \\ M Poggenpoel, Ph.D, Department of Nursing, RAU \\ A Gmeiner, D.Cur, Department of Nursing, RAU
}

\section{Summary}

Malawi has a population of 9 million people with AIDS the leading cause of death in the $20-40$ age group. The HIV positive prevalence rate, estimated at $23 \%$ in urban areas and $8 \%$ in rural areas, is one of the highest in the world (AIDSEC, 1994:1). Evaluation of counselling practices showed poor results with counsellors feeling ineffective and inadequate. Patients are mostly tested on medical indication but patients who do not see the benefit of knowing their HIV status increasingly refuse testing.

The counselling practise as it is known in the Western world is a foreign concept for patients living in rural Malawi. The high stigma of AIDS complicates support of the patients. The goal of the research study was to describe a model of counselling that would meet the needs of an AIDS patient in rural community in Malawi. A qualitative research design that was explorative, descriptive and contextually specific to rural Malawi was used for the study. In order to describe a counselling model it was important to understand the illness experience of HIV reactive patients. The patients are seen in group context congruent with the African culture and therefore the experience of the primary care giver of AIDS patients is explored as the other major factor in the phenomenon examined. One phase of the research is described in this article namely exploring and describing the experience of the HIV reactive patient in rural Malawi.

Results show that patients are in an advanced stage of AIDS when they are diagnosed and complain of weakness and an inability to do work, including an inability to do their daily chores. This causes a feeling of desperateness that is worsened by the perception that support systems are inadequate. Support systems are mostly identified as parents, partners and siblings to assist mainly with the physical care and financial support. Despite the fact that the family is very important to patients there is a reluctance to acknowledge their HIV status. Patients fear being rejected once it is known that they have AIDS - not only because AIDS is a sexually transmitted disease, but also because it is perceived that financial and other support will be withheld if it is known that patients have AIDS and will therefore die and not be able to return the support provided. Patients feel they have no future once a diagnosis of AIDS has been made which results in refusal of testing, as they do not see the benefit of knowing their HIV status. Assessing the coping ability of the patient within the household as part of an overall assessment is one proposed strategy that could be taken. Secondly the patient is encouraged to take a more active role in the counselling process, which could be achieved by narration. The family should be incorporated into the counselling process as early as possible.

\section{Opsomming}

Malawi het ' $n$ bevolking van 9 miljoen mense, met VIGS die vernaamste oorsaak van dood in die ouderdomsgroep tussen 20 en 40 jaar. Die voorkoms van HIV, beraam op $23 \%$ in stedelike gebiede en $8 \%$ in die plattelandse areas, is een van die hoogste ter wêreld (AIDSEC, 1994:1).

' $n$ Evaluering van die beradingspraktyke het swak resultate getoon met beraders wat oneffektief en ontoereikend voel. Bloed ondersoeke vir HIV word oor die algemeen gedoen na aanleiding van mediese aanvraag, maar toestemming om die ondersoek te doen word verder toenemend geweier deur pasiënte wat nie die voordeel insien om te weet wat hulle HIV status is nie. Berading soos dit in die Westerse wêreld bekend is, is ' $n$ vreemde konsep vir pasiënte wat op die platteland in Malawi woon. Die hoë stigma verbonde aan VIGS bemoeilik ondersteuning aan die pasiënte in " $n$ plattelandse gemeenskap in Malawi. Die doel van die navorsingstudie was om ' $n$ model vir berading te beskryf wat aan die behoeftes van " $n$ VIGS pasient in die plattelandse gemeenskap van Malawi sal voldoen. ' $n$ Kwalitatiewe navorsingsontwerp wat verkennend, beskrywend en kontekstueel spesifiek is aan die platteland van Malawi, was in die studie gebruik. Om 'n beradingsmodel te beskryf, was dit belangrik om die siektebelewenis van die HIVreaktiewe pasiënte te verstaan.

Die pasiënte is benader in " $\mathrm{n}$ groepskonteks wat kongruent is aan die Afrika kultuur en daarom is die belewenis van die primêre versorgers van VIGS-pasiënte ook ondersoek. Slegs een fase van die navorsing word in hierdie artikel beskryf, naamlik die verkenning en beskrywing van die belewenis van HIV-reaktiewe pasiënte in die plattelandse gemeenskap van Malawi. Resultate toon dat pasiënte reeds in ' $n$ gevorderde stadium van VIGS is wanneer hulle gediagnoseer word en dan kla dat hulle swak voel en nie kan werk nie. Hulle kan ook nie hulle daaglikse take uitvoer nie. Dit veroorsaak ' $n$ gevoel van desperaatheid wat vererger word deur die persepsie dat hulle ondersteuningstelsels ontoereikend is. Ondersteuningstelsels word meestal geidentifiseer as ouers, intieme maats en broers/susters, om hulle veral fisies en finansieel te ondersteun. Ten spyte daarvan dat die familie baie belangrik vir die pasient is, is daar tog huiwering om hul VIGS status te erken. Pasiënte vrees verwerping as dit bekend word dat hul VIGS het nie net omdat dit ' $n$ seksueel oordraagbare siekte is nie, maar die persepsie bestaan ook dat finansiële en ander ondersteuning onthou sal word as dit bekend is dat hulle VIGS het en sal doodgaan voordat hulle ondersteuning kan teruggee. Pasiënte voel hulle het geen toekoms as die diagnose van VIGS eers gemaak is nie, wat daartoe lei in hul weiering om getoets te word. Hulle sien geen voordeel 
daarin om hulle HIV-status te weet nie. Beraming van die hanteringsvermoë van die pasient binne die huishouding as deel van ' $n$ globale beraming is een voorgestelde strategie wat gevolg kan word. Tweedens kan die pasient aangemoedig word om ' $\mathrm{n}$ meer aktiewe rol in die beradingsproses te speel, wat op " $n$ narratiewe manier gedoen kan word. Die gesin behoort ook so gou as moontlik geÏnkorporeer te word in die beradingsproses.

\section{Background/problem statement}

In Malawi Human Immunodeficiency Virus (HIV)/Acquired Immune Deficiency Syndrome (AIDS) has become one more problem amongst many others facing the continent of Africa. The HIV infection is a major and rapidly growing health problem that is not limited to a small high-risk segment of the population. The first seven cases in Malawi were reported in 1985. Since then, according to figures supplied by the AIDS Secretariat of the Ministry of Health (AIDSEC), the number of cases has grown steeply. The prevalence of HIV/AIDS resembles that of highly endemic countries in Africa. By June 1994 a cumulative total of 34866 AIDS cases had been reported. Of these $92 \%$ were adults and $4 \%$ were children below five years. This HIV prevalence is estimated at $23 \%$ in urban areas and $8 \%$ in rural areas is one of the highest in the world. Studies of antenatal mothers in Lilongwe and Blantyre confirm a sharp rise of HIV infection, from 8,2\% in 1985 to about $32 \%$ in 1994 (Malawi AIDS Control Programme, 1994).

The high incidence rate of HIV/AIDS in Malawi has had a big impact on the health services in Malawi. The number of patients has increased and health services have become overstretched. Counselling services, before the endemic a fairly unknown concept within the health sector, are now recognised as an important component of the health care provided for HIV/AIDS patients although the concept is still unknown to patients, especially in rural areas.

The counselling model presently used is individual orientated that could cause alienation from the group (family and community) to whom the patient belongs. The Africa context from which the patient comes is not sufficiently taken into consideration in the person centred counselling approach. It does not actively facilitate acceptance and integration of the individual with a known HIV status back into his/her family and community. For the African person belonging forms an essential and central part of well being and therefore needs to be integrated into the counselling approach.

During the year prior to the research being conducted, the researcher became aware of the fact that the patients did not feel that they benefited from being counselled in relation to HIV/AIDS issues. There was also a growing tendency by the patients to refuse HIV testing, as their knowledge of AIDS increased. Counsellors further felt frustrated in their work and saw themselves as messengers of death. The National AIDS Programme confirmed this observation made by the researcher during an evaluation done on the effectiveness of counselling services in 1992.

In lieu of the above the following research question was asked: - What approach to counselling would be specific in meeting the needs of HIV/AIDS patients within a family and community context in a rural area in Malawi?

From the research question the goal and research objectives have been formulated as follows:

\section{Research objectives}

The overall aim of this research was to describe a model of counselling HIV reactive patients that would meet the needs of such a patient in a rural African community in Malawi.

The following objectives were set:

1. To explore and describe the HIV reactive individuals experience of illness;

2. Compile a demographic profile of the patient in the study and describe who the patient identifies as possible resources and why;

3. Explore and describe the experience of care givers of an AIDS patient;

4. Explore and describe the viewpoint of counsellors in terms of counselling HIV reactive patients.

For the purpose of this article objective one will be the focus, namely to explore and describe the HIV reactive individual's experience of illness.

In Part II of these articles, the development of a counselling model based on the findings of the research study that will meet the needs of AIDS patients within a community context in rural Malawi will be described.

\section{Research design}

A qualitative, explorative, descriptive and contextual research design was utilised in this part of the research (Mouton \& Marais, 1992: 45, 175).

The focus was to obtain data by means of phenomenological interviews that would facilitate understanding of HIV reactive individuals' experience of illness. This will then form the basis for developing a care-counselling model.

\section{Assumptions of the researcher}

The researcher accepted the following assumptions from Nursing for the Whole Person Theory:

- $\quad$ Focus is on the whole person - body, mind and spirit;

- $\quad$ Emphasis is on the continued quest for wholeness of the individual within the family and the community;

- $\quad$ Reaches out to the community by the rendering of a nursing service based on nursing education and nursing research to facilitate the community's quest for wholeness (Oral Roberts University, Anna Vaughn School of Nursing, 1990: 136 - 142; Rand Afrikaans University, Department of Nursing, 1992).

\section{Symbolic interactionism:}

- Symbolic interactionism aims to be neutral and takes a non-judgemental position (Boesch, 1991: 1 \& Goffman, 1957: 127).

- Illness is conceptualised as an interactive process 
between the patient and society in which time is an important consideration in the influence and re action of society on people (Becker, 1963: 14).

It is not the symptom or the illness that the patient develops that matters but how the environment responds to the illness (Gerhardt, 1989: 82).

Research model in qualitative methodology (Botes, 1992: 36):

- The goal and aim of the research is aimed at giving action-related prescription within a specific context. The usability of the results will serve as guideline for validity.

- $\quad$ A mutual relationship between the paradigm, research and theory development and the practice is presupposed.

- Trustworthiness in qualitative research will now be discussed.

\section{Trustworthiness}

Lincoln \& Guba's (1985: 218 - 331) four strategies for trustworthiness were followed. These were truth-value, applicability, consistency and neutrality. The researcher had extended exposure to the research field in Malawi. She kept reflective field notes that formed part of data collection. Triangulation of data collection and data control was executed. A dense description of data by the researcher provided the required information to other researchers, should they want to prove transferability. Confirmation was ensured by means of an audit trail. The researcher placed her in "brackets" and entered the field from a "don't know" position in order to gain an understanding of the HIV patients' experience of illness.

\section{Research method}

In this phase attention will be given to sampling, data gathering, data analysis and literature control. As trustworthiness for the research has already been described, ethical measures to enhance trustworthiness of this research will be discussed.

\section{Sampling}

The sample was taken from a population in which the phenomenon is explored. Critical theory qualitative researchers employ purposive and not random sampling methods (Glaser \& Strauss, 1967: 65). Groups and individuals were sought out where the processes and studies were most likely to occur (Glaser \& Strauss, 1967: 65). In addition to purposive sampling, snowball sampling was also used. Snowball sampling involves subjects suggesting other subjects to the researcher, so that the sampling process gains momentum, like a snowball rolling down a hill (Wilson, 1989:261). Snowball sampling was necessary because of the high stigmatisation of AIDS and patients would have to be introduced to the researcher to ensure that confidentiality was not broken.

For in-depth phenomenological interviews it is not the number of participants interviewed that is important, but rather that the inner world of the interviews is described as completely as possible. It is accepted that the sample is big enough once a repetition is seen in the description of the participants (Parse, Coyne \& Smith, 1985:18). For that reason participants will be interviewed until data has been saturated and new themes no longer emerge. See Table 1 for sampling criteria.

\section{$>\quad$ Data Collection \\ - $\quad$ Phenomenological Interviews}

Use was made of in-depth phenomenological interviews as described by Kvale (1983: 174 - 179), with the purpose of describing the life-world of the participant with respect to interpretation of the meaning of the described phenomenon. Technically the qualitative research interview is "semi-structured", being neither a free conversation nor a highly structured questionnaire. An interview mode that focused on themes rather than on exact questions was followed. The interview was taped and transcribed verbatim.

A central question was asked during in-depth phenomenological interviews to the HIV/AIDS patients:

"Please describe how you experience being HIV reactive". After initial contact with the patient, selected according to the sampling method, informed consent was obtained. Date, time and place for the interview were confirmed.

The interview was conducted in private. The participant was made comfortable for the duration of the session. A high quality tape recorder was strategically placed to capture dialogue between the moderator and the participant. The researcher conducted the interviews with the help of a trained counsellor who served as interpreter. The researcher and interpreter were skilled in the techniques of conducting interviews.

The interview was conducted in Chichewa. The interview was non-directive but the participant was encouraged to discuss all aspects of being. Themes mentioned by the participant were explored deeper. If the patient showed signs of physical or mental fatigue the session was terminated. Field notes were

\section{Table 1 : Sample population for in-depth phenomenological interviews}

\begin{tabular}{|l|l|l|}
\hline Sampling Population & Criteria for sampling & Sampling Method \\
\hline $\begin{array}{l}\text { HIV/AIDS patients: } \\
\begin{array}{l}\text { All patients who have received post test } \\
\text { counselling at the identified hospital } \\
\text { and who have been discharged back to } \\
\text { the community within a 10km radius } \\
\text { of the same hospital }\end{array}\end{array}$ & $\begin{array}{l}\text { A person of either sex over the } \\
\text { age of } 15 \text { years } \\
\text { HIV status reactive } \\
\text { Informed consent obtained to } \\
\text { participate in the study }\end{array}$ & $\begin{array}{l}\text { Snowball sampling taken from the } \\
\text { counsellors who have counselled pa- } \\
\text { tients who meet the criteria and can be } \\
\text { followed up in the community }\end{array}$ \\
\hline
\end{tabular}




\begin{tabular}{|c|c|}
\hline INTERNAL WORLD & EXTERNAL WORLD \\
\hline $\begin{array}{l}\text { 1. BODY } \\
\text { 1.1 Physical symptoms } \\
\text { - } \quad \text { Experiences pain } \\
\text { - } \quad \text { Complains of weakness } \\
\text { - } \quad \text { No more sexual relations } \\
\text { - } \quad \text { Recovered after initial illness } \\
\text { - } \quad \text { AIDS is tougher than other illness } \\
\text { - } \quad \text { Had TB when diagnosed with HIV } \\
\text { - } \quad \text { Lith malaria symptoms more severe } \\
\text { - } \quad \text { Soss of weight } \\
\text { - } \quad \text { Felt more sick after giving birth } \\
\text { - } \quad \text { Temporary amenorrhoea } \\
\text { - Coughed at time of diagnosis }\end{array}$ & $\begin{array}{l}\text { 1. PHYSICAL } \\
\text { - } \quad \text { No financial support } \\
\text { - } \quad \text { Poverty since illness }\end{array}$ \\
\hline
\end{tabular}

\section{MIND}

\subsection{Intellect}

2.1.1 Perception

- Family also has difficulties

Hospital can help

God gives guardian strength

Support from home is important

Acceptance of AIDS as fatal illness

Preoccupation with illness

Patient want to know diagnosis

Should not have sex with another

2.1.2 Coping mechanisms

- $\quad$ Avoids talking about AIDS

- Rationalises

- Little understanding

- Claims not to know cause

\section{SOCIAL}

- Fails to do work

- Support systems are weak

- Involves family

- $\quad$ Tries to do easy tasks

- Family should not know

- $\quad$ Told parents of HIV status

- Family knows but denies AIDS

- Wants to divorce husband

- Feels socially isolated

- Patient active in community

- Wants to socialise

\subsection{Emotion}

2.2.1 Feelings

- Worried about children

- Anxious about transmission risk

- Despair

- Unhappy

- Anger

- Guilt

- Confusion

- Rejection

- Lonely

- Scared

- Conflicting feelings

\section{SPIRIT}

3.1 Community

- Looks upon God for help

- Heaven gives eternal life

3.2 Conscience

- $\quad$ AIDS is morally wrong

- Need to confess about sins

Should contribute to community

\section{SPIRITUAL}

3.1 Community values

- AIDS reduces person 


\begin{tabular}{|c|c|}
\hline INTERNAL WORLD. & EXTERNAL WORLD \\
\hline $\begin{array}{l}\text { 1. BODY } \\
\text { 1.1 Physical symptoms } \\
\text { - Experience of death }\end{array}$ & $\begin{array}{l}\text { 1. PHYSICAL } \\
\text { - No financial support }\end{array}$ \\
\hline 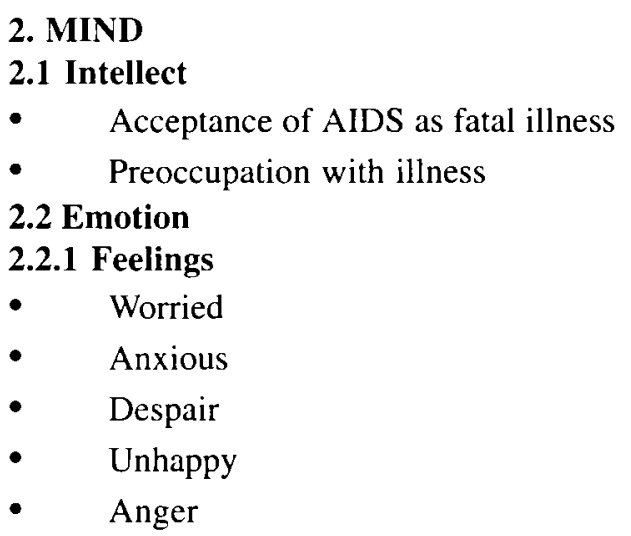 & $\begin{array}{l}\text { 2. } \text { SOCIAL } \\
\text { - } \quad \text { Fails to do work } \\
\text { - } \quad \text { Support systems weak } \\
\text { - } \quad \text { Family involvement }\end{array}$ \\
\hline $\begin{array}{l}\text { 3. SPIRIT } \\
\text { 3.1 Community } \\
\text { - Looks upon God for help }\end{array}$ & 3. SPIRITUAL \\
\hline
\end{tabular}

made during the interview as validation of the taped comments. Key insights were also recorded during the session (Wilson, 1989:436-438).

\section{$>\quad$ Data Analysis}

For the analysis of the in-depth phenomenological interviews a combination of Giorgi's (in Parse. Coyne \& Smith. 1985: 19 23) method of phenomenological analysis and content analysis of Kerlinger (1986: 477 - 480) was used.

Combined with this method of phenomenological data analysis as expanded by Parse et al (1985: 22-24) content analysis was conducted according to the method of Kerlinger (1986: 477). Content analysis is a method of analysing communication objectively and systematically. The researcher transcribed the interviews and observed and measured the variables (Wilson. 1989: 469, Kerlinger, 1986: 477).

The analysis consisted of compiling demographic information and other notes about the participants. The audiotapes were transcribed and used in combination with the notes. Transcriptions were first read to obtain an understanding of the whole experience of the person interviewed and then themes were described.

The themes were placed in the context of the unit of assessment and diagnosis in the Nursing Theory for the Whole Person (Oral Roberts University, 1990; Rand Afrikaans University, 1991), namely internal environment (body, mind and spirit), external environment (physical, social and spiritual) and characteristic interaction between the internal and external environment. Results were tabulated in table 2 . discussion can be seen in table 3 .

A protocol was designed and given to two independent experts with the request to analyse the transcribed data. The two independent experts were two psychiatric nurse specialists, with experience and knowledge of the research method. The protocol and transcripts were received independently by the psychiatric nurse specialists to analyse the data. The researcher met with each of the two experts to compare their analyses. The results, together with all the analysed data were presented to the Malawian researcher at the Centre of Social Research for further validation and as an additional measure of reliability. Results were presented to the AIDS Secretariat in Malawi to be compared with existing data.

\section{$>\quad$ Ethical Measures}

At all times during the research participants were ensured of anonymity. Informed consent was obtained before any interviews were held. All participation was voluntarily (Parse, Coyne $\&$ Smith, 1985: 18). Using snowball sampling of primary care givers ensured confidentiality. Results of HIV tests were only given to patients and only by the request of a patient to other persons. The Department of Research and Environmental Affairs obtained official permission and Government clearance. Feedback regarding the results has to be given to the Department.

\section{Results/Discussion of Results}

A total of 8 interviews were conducted with patients infected with HIV within one district of Malawi. To obtain better insight into the circumstances and needs of the patients, interviews were also conducted with 6 primary care givers of AIDS patients and with 6 counsellors. In addition focus interviews 
were held with all patients at the identified hospital who consented to participate in the study for the duration of one year.

The researcher experienced gathering and analysis of data as extremely tiring and the material painful to work with. Similar feelings were verbalised by the independent coders that correlated with the feelings experienced by the counsellors. An overwhelming feeling of helplessness was generally described.

The counsellors were used as indicators in the identification of the patients, which worked well because it was possible for the counsellors to do follow-up counselling after the completion of the interviews.

A summary of the results will be now discussed shortly, before describing results in more detail.

\section{Summary of the results of the in-depth interviews conducted with patients}

\begin{abstract}
When patients were tested for HIV at the hospital
\end{abstract} they were already in an advanced stage of the illness, which was demonstrated by their complaints of pain and general weakness.

- $\quad$ Patients seemed to accept having AIDS but did express despair about the course of the illness, both in terms of the physical impact as well as experiencing an sense of not having a future perspective. God was referred to as a source of strength during this time. Patients also seemed preoccupied with being sick. Feelings of unhappiness and anger were expressed, but mostly in an indirect way.

- Inability to do work, including doing daily chores, was a general complaint that created a feeling of desperateness worsened by the perception that support systems were weak.

- $\quad$ Patients involved family for emotional support but did not actually tell the family that they are HIV infected. They were especially in need of financial support from the family - this need was not met. There was also a complaint of increased poverty after the onset of the illness.

Patients were very worried about the impact of illness on their families. Particular concern was expressed regarding HIV transmission risk.

\section{Discussion of the illness experience}

The illness experience of the patient will be discussed and techniques to help the patient to express his/her experience will be explored. The identified strengths of the patient will further be discussed. Refer to Table 3 for the most important themes generated by patients. These themes will now be discussed with direct quotes from respondents, as well as literature control.

\section{Factors of the internal world}

\section{$>\quad$ Physical symptoms - pain}

The physical suffering of AIDS patients is severe. The results of the in-depth interviews indicated that patients were physically weak and complained of pain at the time they were counselled. This partly due to the fact that the diagnosis is made only when the patient has already reached an advanced stage of the illness. As on respondent stated:

"I've been feeling pain in my body and that is when I came to hospital for treatment ... September it started with the leg, a painful ankle and after that I had pain on one side of my back and then I had general malaise, headache, too..."

and

“... my body had much pain and weakness and I wanted to sleep all the time..."

One patient spoke of pain indirectly by referring to his scars that he had from shingles (herpes zoster), but did not complain of pain during the interview. Another patient was in pain during the interview but did not discuss it. Doka (1993: 4) speaks about the pain and adds by saying that if one takes into consideration psychological, spiritual, sexual and financial levels, it is understandable that in the case of many patients the topic of pain dominated the interviews. It could be said that pain is the physical fact of the illness and that suffering is how one responds to the illness.

The physical pain is also not merely a physical manifestation of the disease, but can also be an emotional response to a physical perception, in which case it should rather be called suffering (Doka, 1993:4-14).

\section{$>\quad$ Mind - intellect \\ - Acceptance of having a fatal disease}

An understanding of the fatality of AIDS was shown with an acceptance of the course of the illness. It was actually more the way in which the patient spoke that demonstrated that acceptance. It was described in the following way:

“... just staying and preparing about my spiritual life... Because I know that if there would be some cure it would have been given and people would have been cured..."

and

"I had to learn to cope with it ... I do not blame anyone for giving me the infection and I do not blame myself either ... So I try to lead a happy life..."

Doka (1993: 67) states that the patient's understanding of the disease may be very different from the professionals understanding. A realistic understanding becomes important, but also learning to cope in a way that allows continued hope. A sense of control can lower a patient's level of anxiety.

These patients then use acceptance as a way of coping, according to Murphy \& Moriarty (1976: 25) includes defence mechanisms active ways of solving problems and methods of handling stress. In coping one try to return to a way of life that seems normal. One adjusts one's expectations and searches for courses of action that will enable one to achieve whatever goals are culturally significant (Barnett \& Blaikie, 1992: 39). Namir et al (1987: 309) adds to this by stating that active behavioural coping led to better functioning of the patient and was 
generally more helpful. The study considered at the identified hospital in rural Malawi pointed out passive coping (low activity) with a high level of acceptance. Meursing \& Sibindi (1992: 4) found similar results in Zimbabwe.

\section{- $\quad$ Preoccupation with illness}

There seemed to be a preoccupation with the illness that increased with the progression of the illness. The following statements were made:

"... thinking about the disease which I have, since they say" there is no drug, there is no cure for it..."

and

“... I can only stay in bed and not do any work. Only stay in bed and think all the time..."

A critical time during the HIV infection is the time of diagnosis. It is a stressful event and the reaction of the patients often determines how will they cope in the future. A natural response to the diagnosis can be that the patient becomes extremely aware and sensitive to his/her body and any symptoms can become the focus of great concern (Doka, 1993: 3). One of the threats of disability is that it can easily become the expectation of both the patient and the family that the patient is dependent and helpless. Once the patient knows that certain behaviour is expected, he/she lives up to that expectation (Scheff, 1966: 93). A permanent role of disability is often easier to take on. The patient becomes excluded from the usual community activities that are damaging to the patient's self-esteem (Gerhardt, 1989: 110).

\section{$>\quad$ Emotions \\ - $\quad$ Feelings

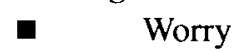

They described being especially worried about their children. who are in need of assistance. They describe it as follows:

“... I was worried because I've got small kids so I knew if I leave these kids they would be orphans ... there is no-one to look after them..."

and

"... my child and my younger brother have to go to school but nobody wants to help with school fees and school uniforms"

\section{- Anxious about transmission of HIV}

Patients were very concerned about the risk of infection. Different anxieties concerning transmission were expressed:

A patient expressed concern about infecting his partner when told that he was HIV reactive:

“... I think about my wife who also has the virus because we have been together" (meaning they had sexual intercourse) and the HIV infected mother who already has one child in the last stages of AIDS:

"... I am very worried. This is my first husband and I have never had another man. I know this virus has come from my. husband because he has many partners. He left South Africa ... It is not good to have children like this..." (points to the very sick baby on her lap)

and

“... but I still do worry because I really don't know how the virus got into my body..."

Despair as a feeling connected with a sense of helplessness
Patients did not always express feelings openly, but their feelings could be sensed from other things they said:

"... and what is this virus going to do to my body..." and

"... I would see myself that my future has ended ... So when somebody says I do not have a future, that thing can make you even want to commit suicide. If I do not have a future I do not deserve living. So I just need to make a suicide..."

- Unhappiness depending on personal circumstances

Patients did not describe themselves as unhappy, but the feeling emerged as a theme because it can be deducted from what the participants said, as well as field notes taken:

" ... it's hard to be happy when you are still in hospital but if maybe I could go home then I would try to be happy with my children..."

and

“... I am lonely and not happy because I do not get any help from my relatives. Sometimes I can speak to my mother. But when I tell her I feel sick and I need to go to the hospital, she does not help me..."

- Anger as a result of being infected with HIV Patients did not identify anger as a feeling but expressed it indirectly in the following way:

“... I am deciding that when my husband comes to the hospital to see the baby I want to tell him this is the end of the marriage. Because of the baby who is now also infected..." and

“... when I was healthy many people would visit and help me. But since I fell sick nobody does ... If I have food they do share with me but if they have food they do not share it with me..."

From the above, it seemed that different emotions were identified during the in-depth interviews with patients, at times these emotions even seemed to be contradictory. According to Doka (1993: 2) each person as well as different individuals can experience a range of emotions, often contradictory emotions, simultaneously. Guilt and shame are common reactions to a life threatening illness. A person may believe that something in her/his personal behaviour contributed to contracting the disease. This is especially true in the case of HIV. It can further be seen as a punishment from God for what is believed to be a sinful and immoral behaviour (Doka, 1993: 14).

The patient could also feel guilty about the fact that he/she is no longer able to perform the usual household duties and about the fact that they may have become a burden to others. Anger can be expressed at self, others (family and friends) or care givers (Doka, 1993: 15). Fear and anxiety are caused by the crisis the person is in, because of the loss of control, as well as the pain and suffering. Grief and sadness are experienced not only in response to what is actually happening but also in anticipation of what could happen in the near future. All these feelings may also explain why people feel disengaged and withdrawn from others. The patient may withdraw because of intense anxiety, pain or other feelings (Doka, 1993: 14-22).

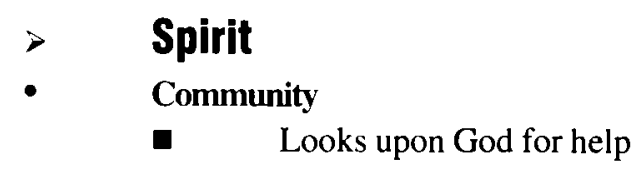


The patients were reaching out to God as an additional source of strength and found relief in their personal belief system. They were very definite in their expression thereof:

"... there is no one. Only God can help me..." and

"... God will look after me and my baby ... and I think God, He gave her the strength to take it ... I need to keep my promises. I would like to see the end of it. Though it is too short I need to accept it ... and I think God honoured it ..."

In a study by Christie, Ramakhula \& Zazayokwe in South Africa in 1993, religion was identified as one of the sources of strength and coping for the patient. The researcher founded similar results as the patients, care givers and counsellors often mentioned God as a source of strength. Religious and philosophical beliefs, and especially belief in the afterlife, can be a great source of comfort.

\section{Factors of the external world}

\section{$>\quad$ Physical}

\section{- $\quad$ No financial support}

There is an automatic dependence on the extended family for financial support and if such support was lacking it placed the patient in a crisis. Patients expressed their needs in the following statements:

“... more problems because everybody know's that one has to eat, one has to feel happy with their life and one has to have clothes to put on ... There is no one ..." (to help)

and

" ... my brother is in Zambia but even though he is healthy he does not want to help me. Nobody wants to give me a coin to make things easier ..."

The impact of illness and death is felt very strongly in Malawi. Apart from having to face the loss of a family member, there are some additional responsibilities, demands upon time, financial effects as well as social consequences (Doka, 1993: 161). The family's financial status is likely to be adversely affected and this endangers the balance within the family. Children under five years of age in poor rural families tend to be the first ones to suffer from malnutrition if sources become scarce in a household. The financial burden on the patient becomes a crisis for the family.

In Malawi, for marriages, school fees and medical, amongst other expenses or favours of whatever kind, rural people first turn to their extended families (Hulme \& Turner, 1990: 85). AIDS has placed a particularly strenuous and ongoing burden on communities whose resources are depleted and are not being replaced, because income-generating adults are falling away (Barnett \& Blaikie, 1992: 106).

\section{$>\quad$ Social}

\section{- Failure to do work}

Performing daily tasks and work were regarded as essential in the lives of those infected with HIV. They described the importance of work in their daily lives:

“... you cannot do any other job by yourself even drawing water, cooking you can't do that ... and I've got four kids ... before I could still work, then it did not matter much, but now I have to stay in bed ..." and

"... I could manage to do some of the work like cooking, but I could not manage to dig in the garden or to fetch firewood..."

What happens to the whole household if a member is sick, can be described as follows: Firstly, there is a loss of income earning opportunities, the sick household member cannot perform everyday routine tasks and there is diversion of productive labour time to care for the sick, diversion of cash for medical expenses, diversion of food reserves to funeral ceremonies and cash for a coffin and other funeral expenses (Barnett \& Blaikie, 1992: 106). This means that you find an increasingly burdened household. This makes life very difficult for the families who come from a lower socio-economic background. Chronic illness poses a severe threat to resources and while a reduction of resources is inevitable, what differs is the amount and duration (Strauss \& Glaser, 1975: 74; Gerson, 1976: 799).

\section{- $\quad$ Support systems weak}

It seemed that the availability of additional support systems could make a difference to the experience of illness by the patient. Relatives were regarded as a support system and if there was problem in this area, the patients were specific about mentioning it.

A few patients expressed difficulty in this area:

"... there is no one to help me. Only my first born who is a boy..." (nine years old)

and

" ... my mother is very weak too and can not manage to keep them ... The eldest child. She is the only one, seventeen years of age, so she is doing all this because there is no on else that can do it..."

\section{- $\quad$ Family involvement}

Patients did involve family members in their illness but did not always make it explicitly clear to the family involved that they were actually HIV infected.

The following statements were made:

“... when I was told I came to tell my parents that I have been found with the virus. My brother has been trying hard to buy some local medicine from Lilongwe and give me..."

and

"... so my sister came and advised me not to worny much. No one will fly to heaven all of us will go the same journey: You get sick and then you die ... I didn't tell her..." (that she has AIDS)

In-depth interviews indicated the patients and the caregivers feared that family members would no longer support them when it became known that the patient had AIDS. AIDS means death and thus the inability of the patient to return the support. either financially or in kind.

Family members may be able to provide support and home based care for the patient, but it would be unrealistic to think that the people expected to provide the service meet their obligations with selfless devotion and that everybody is consequently happy (Hulme \& Turner, 1990: 85).

Families, just like individuals, will have to try to integrate the experience of a family member's illness into their ongoing life. 


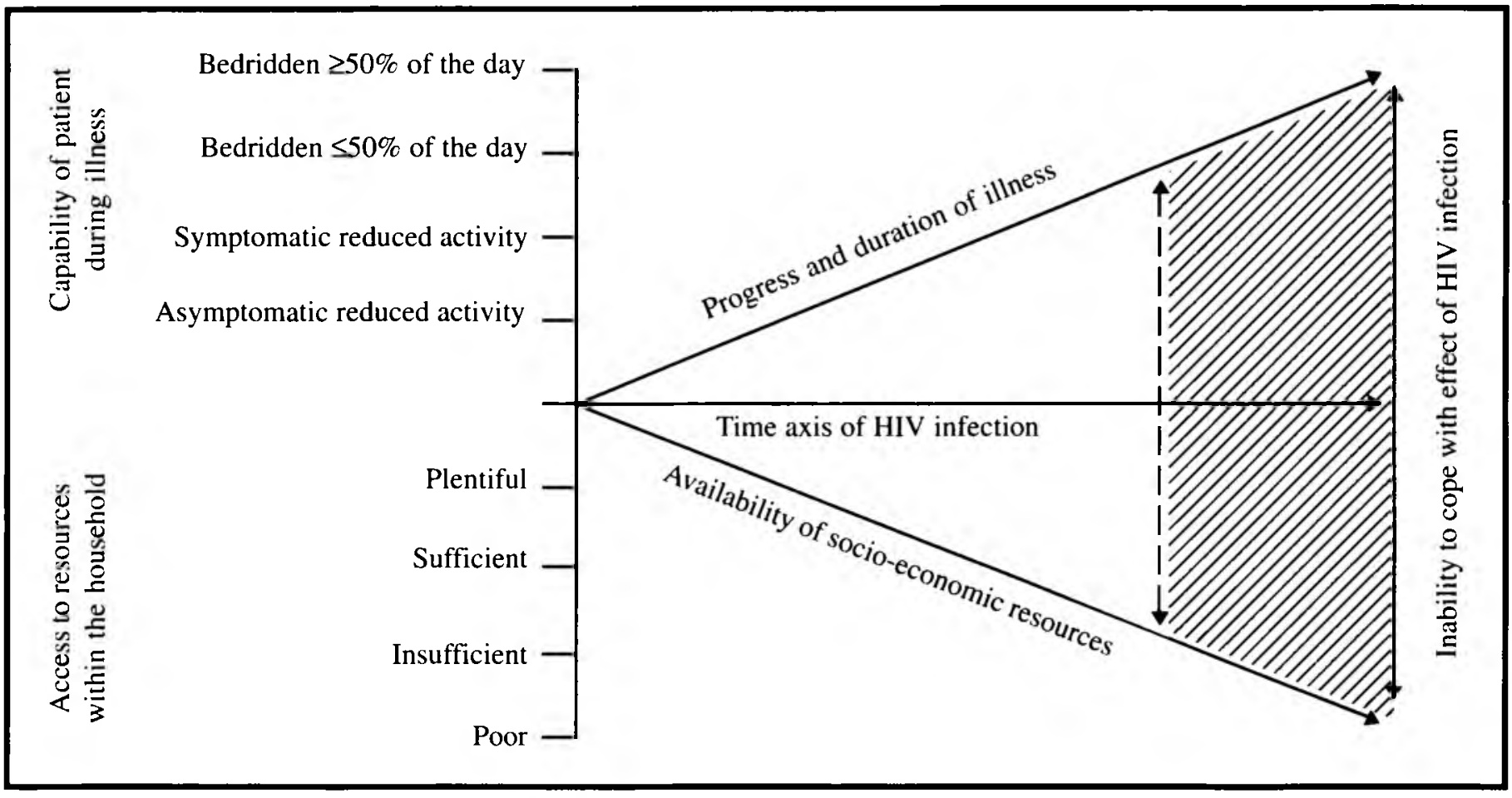

Needs from before the illness will remain the same. Families, just like patients, will have different degrees of success in coping with the variety of problems they face (Schneidman, 1978: 37; Rando, 1984: 74 \& Doka, 1993: 171 - 187).

\section{Conclusions and}

\section{recommendations}

It was clear from the results from the in-depth, phenomenological interviews that the participants experienced many stumbling blocks in their quest for health/mental health. They need a variety of support, not only from their family, but also the community. Important additions to the previously used counselling is needed to identify and deal with the actual needs expressed by the patient including physical and socioeconomic needs and to assess the coping ability of the patient within the household.

Further is it important to encourage the patient to be a narrator in the counselling process that is congruent with the Africa culture. The patient should be seen as part of a family on which the patient relies for support. Early involvement of the family will counteract rejection, promote problem-solving ability and mobilisation of resources. It will further decrease HIV transmission risk with the opportunity to provide information.

\section{Strategies for the future}

One of the main strategies to strengthen the patient within the household and community is to assess the coping ability of the patient within the household. Results have indicated that the physical state of the patient and the availability of resources especially are very important factors in determining the coping ability of the patient and the household. Social class and income levels affect the experience of illness. High social class and more resources lead to more options when coping with the illness. For the purpose of clarity the researcher has designed a diagram (see Figure 1) to illustrate the effect of the physical state of the patient and the availability of resources on the ability or inability of the patient $t$ cope with the impact of the HIV infection.

From Figure 1 it can be seen that the further and the longer the duration of the HIV infection and the less available the socioeconomic resources, the greater the inability becomes for the patient and the household to cope with the effects of HIV infection.

According to the research conducted by this researcher the majority of the patients are only diagnosed to be HIV infected when they are already bedridden to some degree. Results have further shown that patients tend to be from an environment where socio-economic resources are insufficient or poor. This combined with the severity of the illness, leads to a greater inability to deal with the results of the infection.

For the counsellor to form a better understanding of how the patient and the household are affected by the illness an assessment can be made to determine how able the patient and the household are to cope with the effect of the illness. 


\section{Bibliography}

AIDS SECRETARIAT (AIDS CONTROL PROGRAMME), Ministry of Health Malawi 1994: HIV/AIDS Annual Report, Lilongwe, Malawi.

BARNETT, T \& BLAIKIE, PM 1992: The possible impact of AIDS upon food production in East and Central Africa. Food Policy. 14(1), February 1989: 2 -6.

BECKER, H 1963: Outsiders: Studies in the sociology of deviance. New York: Free Press.

BOESCH, EE 1991: Symbolic action theory and cultural psychology. Berlin, Germany: Druckhaus Beltz.

CHRISTIE, G; RAMAKHULA,S \& ZAZAYOKWE, M 1993: A comparison of crosscultural training for AIDS counsellors in Southern Africa. Johannesburg: AIDS Centre, South African Institute for Medical Research, Johannesburg.

DOKA, KJ 1993: Living with life-threatening illness. A guide for patients, their families and caregivers. New York: Lexington Books.

GERHARDT, U 1989: Ideas about illness: An intellectual and political history of medical sociology. Hong Kong: Mac Millan Education LTD.

GERSON, E 1976: On the quality of life: American Sociological Reviews. 41, 1976: $793-806$.

GLASER, B \& STRAUSS, A 1967: The discovery of grounded theory. Chicago, Aldine.

GOFFMAN, E 1957: The presentation of self in everyday life. New York: Doubleday.

HULME, D \& TURNER, M 1990: Sociology and development. Theories, policies and practices. Harvester Wheatsheaf: Great Britain.

KERLINGER, FN 1986: Foundation of behavioural research. New York: Rinehart and Winston Inc.

KVALE, S 1983: The qualitative research interview: A phenomenological and hermeneutical mode of understanding. Journal of Phenomenological Psychology. 14, 1983: 171 - 196.

LINCOLN, YS \& GUBA, EA 1985: Naturalistic inquiry. Beverly Hills, CA: Sage.

MALAWI AIDS CONTROL PROGRAMME 1994: Targeted information, education and communication intervention for traditional healers in Malawi. (Presented at the $9^{\text {th }}$ International Conference on AIDS, $4^{\text {th }}$ STD Congress: 7 - 11 June 1993: Berlin).

MEURSING, K \& SIBINDI, F 1992: Coping with HIV; Lives of HIV-positive people in Bulawayo, Zimbabwe. (Paper presented at the $8^{\text {th }}$ International Conference on AIDS: Amsterdam).

MOUTON, J \& MARAIS, HC 1992: HSRC studies in research methodology: 4: Basic concepts in the methodology of the social sciences. Pretoria: Human Science Research Council.

MURPHY, LM \& MORIARTY, AB 1976: Vulnerability, coping and growth. New Haven: Yale University Press.

ORAL ROBERTS UNIVERSITY ANNA VAUGHNSCHOOL OF NURSING, 1990: Baccalaureate and Higher Degree Programs, National League for Nursing, August 1990. Volume I Narrative by Criteria. Tulsa, Oklahoma: Oral Roberts University Anna Vaughn School of Nursing: 13, 136-139, 142.

PARSE, RP; COYNE, AB \& SMITH, MJ 1985: Nursing research: qualitative and practical application. American Journal of Orthopsvchiatry. 58(2). 1988: $281-287$.

RANDAFRIKAANSUNIVERSITY,DEPARTMENTOFNURSING SCIENCE 1992: Nursing for the Whole Person Theory. Johannesburg: Rand Afrikaans University.

RANDO, TA 1983: An investigation of grief and adaption in parents whose children have died from cancer. Journal of Pediatric Psvchology. 8, 1983: 3- 20.

SCHEFF, T 1966: Being mentally ill: A sociological theory. Chicago: Aldine.

SCHNEIDMAN, E 1978: Some aspects of psychotherapy with dying persons. ( In: Garfield, Ed. 1978: Psychosocial care of the dying patient. New York: McGraw-Hill).

WILSON, HS 1989: Research in nursing. Second Edition, Redwood City, California: Addison-Wesley. 